\title{
Comparative Politics of Circumcision Bans in Western Europe: A Causal Narrative
}

\author{
Şener Aktürk \\ Associate Professor, Department of International Relations \\ College of Administrative Sciences and Economics \\ Koç University, Istanbul, Turkey \\ November 7, 2019 \\ sakturk@ku.edu.tr \\ sener.akturk@gmail.com
}

\begin{abstract}
Between 2012 and 2018, a wave of attempts to prohibit and criminalize the circumcision of infant males swept across German-speaking and Scandinavian polities, from Germany, Austria, and Switzerland (all in 2012), to Sweden (2013-2018), Denmark (2016-2018), Norway (2017), and finally Iceland (2018), where it came closest to being approved by the parliament. This article develops a causal narrative of those attempts, highlighting the key actors (for and against) and the chronological sequence of their involvement in the attempts to prohibit circumcision in four Scandinavian polities, which is mostly applicable to the case of Germany as well. First, medical and/or legal professionals advocated prohibition at the national level, which was then politicized by the far right (and/or secularist left) parties, and once the issue became politically salient as such, public opinion polls demonstrated significant support for prohibition. The accumulation of legal and/or medical, as well as partisan and public support for prohibition forced the national legislature to debate the issue. In the meantime, international Jewish and Muslim actors and organizations campaigned against prohibition, which finally provoked the national executives and/or political party leaders to intervene to stop the prohibitionist attempt.
\end{abstract}

Acknowledgments: This paper was presented at the American Political Science Association (APSA) Annual Meeting and Exhibition in Washington, D.C., on Friday, August 30, 2019. I thank Hannah Alarian and Alberto Spektorowski for their comments at the APSA panel, and to Emma Rosenberg for her detailed feedback on a previous version of this manuscript. 


\section{Comparative Politics of Circumcision Bans in Western Europe}

On May 7, 2012, the District Court of Cologne in Germany charged a doctor who performed the circumcision of a four-year old Muslim boy with "causing bodily harm to another person by using a dangerous instrument," and although the doctor was acquitted because his mistake was deemed "unavoidable" due to the lack of a unanimous legal opinion on the permissibility of circumcision under German law until then, this verdict made any future circumcisions illegal throughout Germany (Landgericht Köln 2012; Landgericht Cologne 2012). For example, in the months after the ruling, charges were brought against David Goldberg, an Israeli rabbi performing circumcisions in Germany after this verdict (Nadeau 2012). Some hospitals in Austria and Switzerland quickly followed suit by suspending circumcisions (Telegraph 2012). Between 2012 and 2018, a wave of attempts to prohibit and criminalize the circumcision of infant males swept across German-speaking and Scandinavian countries, from Germany, Austria, and Switzerland (all in 2012), to Sweden (2013-2018), Denmark (2016-2018), Norway (2017), and finally Iceland (2018), where it came closest to being approved by the parliament. In another Nordic European country, Finland, too, first a Muslim (2004) and later a Jewish parent (2010) were criminally prosecuted for the circumcision of their infant boys, with the first case going through all the way to the Supreme Court, which affirmed the parents' right to allow for the circumcision of their infant boys for religious purposes (Askola 2011). Although prohibition of circumcision was briefly and at least partially implemented in the three Germanspeaking countries (Germany, Switzerland, and Austria), and proposals for prohibition were brought to the parliament for approval in all four Scandinavian countries (Denmark, Iceland, Norway, and Sweden), the prohibitionist campaigns failed in all seven polities. 
Despite the seeming failure of the prohibitionist attempts, the international campaign against circumcision is supported by the medical doctors' associations and the public in these Germanic and Nordic countries, as well as by some European supranational organizations such as the Parliamentary Assembly of the Council of Europe, which recommended member states placing restrictions on the circumcision of male children in 2013 (Schuz 2015). Therefore, there is reason to suspect that, in the words of one proponent of prohibition, "the necessary debate about circumcision in Germany as well as worldwide has only just begun," (Levey 2013, 449) or, in the words of a somewhat pessimistic opponent of prohibition, "the Cologne state court's decision has let an evil genie out of the bottle" (Goldman 2012). This article contributes to the debate on circumcision by providing a comparative political analysis of attempts to criminalize and prohibit circumcision in eight neighboring northern European countries from 2012-2018.

The paramount significance of the attempts to ban circumcision may not be apparent. Attempts to ban circumcision are very much pertinent to debates over the limits of state intervention in the family, including whether the state or the parents are best equipped in determining the best interests of the child in controversial issues; majority-minority relations, religious liberty; national, supranational, and religious identities; and the debates on tolerating different conceptions of the good life, including whether there is a "neutral" or "secular" conception of the human body (Hirschkind 2011). For many religious individuals, the ability to raise their children in accordance with the minimum requirements of divine law is of supreme importance. Circumcision of infant males is the essential ritual signifying God's covenant with Abraham, and thus, a necessary condition of Jewish identity, even for most secular Jews (Schuz 2015). Similarly, circumcision of males is a highly recommended prophetic tradition (sunnah) in Islam, and although it is not a compulsory requirement of being a Muslim (unlike in Judaism) 
from a theological vantage point, circumcision did become a de facto requirement and a rite of passage for Muslim male children as well. In short, prohibiting the circumcision of male children would in effect deprive most religious Jews and Muslims from having (male) children in the only way that is acceptable from their point of view, and thus, jeopardizing the possibility of a religious Jewish and Muslim family life in Europe.

The Missing Link: The Hegemony of Legal and Medical Arguments, and the Relative Absence of Comparative Political Analysis in Circumcision Debates

German court's controversial decision on 7 May 2012 led to a slew of publications, which, although specifically motivated by the Cologne decision and its aftermath, allowed scholars to (re)articulate their positions in opposition to or in favor of the prohibition of infant males' circumcision in general (Androus 2013; Banai 2013; Levey 2013; Shweder 2013; Van Howe 2013). The overwhelming majority of the works on male circumcision, including arguments both in favor and against, remain within the legal and medical scholarship. To the extent that social scientists engaged with the question of permitting or banning circumcision, they addressed it either in single case studies or from anthropological and political philosophical vantage points (Hirschkind 2011; Amir-Moazami 2016; Yurdakul 2016). Comparative political analyses of attempts to ban circumcision are conspicuous for their absence. This scholarly lacuna is particularly frustrating because it was political interventions rather than legal or medical arguments that determined the various outcomes of initiatives to ban or restrict circumcision in the seven countries that are examined below.

Going beyond national political dynamics, prohibitionist attempts seem to have had a clear spatial and temporal pattern, since they were geographically and chronologically 
concentrated in northern Europe in the 2010s. The six countries where a prohibitionist attempt at the national level was initiated, whether by legal, medical, or political actors, all belong to Protestant-heritage polities, and more specifically "Lutheran Protestant" (as opposed to Reformed Protestant or Calvinist) heritage polities (Kahl 2005). The coincidence of attempted circumcision bans and Lutheran Protestant political heritage provides another very intriguing pattern, which I critically note but cannot explore within the constraints of this paper.

Furthermore, not only national but supranational political actors have been directly involved in the push for prohibition, as the Parliamentary Assembly of the Council of Europe (PACE) passed a resolution in October 2013 warning about the violation of the physical integrity of young boys and recommended considering placing restrictions (Schulz 2015, 347).

An even cursory review of the relevant scholarly literature demonstrates that there is no uniform legal or medical opinion on the desirability, let alone generalizable prohibition or permissibility of circumcision worldwide. Beyond the northern European countries discussed in this article, the "circumcision of males is one of the most common surgical procedures in the world," with “37-39\% of men globally” having been circumcised (Morris et al. 2016, 1), which further highlights the substantive significance and urgency of conducting a comparative historical analysis of the nexus between law, medicine, and politics in the regulation of circumcision.

\section{The Argument: Legal and Medical Professionals, Public Opinion, and Far Right Parties}

The movement to prohibit circumcision is an international one that has been growing, at least in terms of nationwide attempts and "near misses" in particular European countries, if not also in its popularity with the broader European publics. Despite the transnational nature, the 
religious-cultural particularity, and the similarity of the medical and legal arguments employed by the movements seeking to prohibit circumcision in Western, Protestant Christian-heritage democracies, the specific actors, their motivation, and the political alliances that the prohibitionists forge(d) differ significantly between the Anglo-American and the Northern European political contexts. In the Anglo-American context, many adults of Jewish or Christian background, who were circumcised ("the victims"), participate in the campaign against circumcision, whereas in Northern Europe it is mostly if not exclusively non-circumcised people of Christian background who participate in the campaign against circumcision practiced by small Jewish and Muslim minorities. This article focuses on eight Northern European countries where recent attempts at criminalization and/or prohibition of circumcision required parliamentary and/or national political executive intervention to settle.

In Germany and the four Scandinavian polities where attempts at a circumcision ban have come closest to succeeding, the key actors who mobilized and pushed forward the prohibitionist agenda did not include activists who were themselves circumcised men, or alleged "victims" of the practice that they sought to prohibit. In contrast, there was a typical configuration of actors that advanced and resisted the prohibitionist agenda in Scandinavia in six stages. This paper presents a causal narrative of these attempts. First, associations of medical and/or legal professionals initiated the national debate by providing scientific arguments in favor of prohibiting circumcision. Then, Islamophobic far right parties, sometimes in alliance with ultrasecularist leftist parties on the basis of an anti-religious agenda, politicized the issue through petitions and/or parliamentary proposals. Once circumcision became politically salient as such, public opinion surveys on the issue indicated that the broader public was also leaning in favor of prohibition, often with very large margins. Over time, the accumulated pressure of medical 
professionals, far right (and sometimes also leftist) parties, and public opinion, made a national level legislative or executive intervention necessary in order to resolve the controversy in favor of or against the prohibition of circumcision. Consequently, the credible threat of a prohibition on circumcision provoked an international reaction among Jewish and Muslim communities and countries, interlinked with the local Jewish and Muslim minorities. This international reaction often evoked examples of repressive, totalitarian, and even genocidal regimes, ranging from the Roman Empire and Nazi Germany to the Soviet Union, which prohibited and/or stigmatized circumcision as part of their policies of forceful assimilation and persecution against Jews and/or Muslims. Finally, the executive and/or the legislature intervened to thwart the prohibitionist attempt. These six stages, corresponding to six types of actors (italicized in Figure 1), summarize the causal and chronological trajectory of failed attempts to prohibit male circumcision in Western Europe in the 2010s.

\section{Figure 1. Six Stages of Failed Attempts to Prohibit Circumcision in Western Europe}

Stage 1: Medical and/or legal professionals advocate prohibition $\rightarrow$

Stage 2: Far right (and/or secularist left) demand prohibition $\rightarrow$

Stage 3: Public opinion polls show popular support for prohibition $\rightarrow$

Stage 4: Prohibitionist proposal(s) reach and/or debated in the national legislature $\rightarrow$

Stage 5: International Jewish and Muslim organizations/actors intervene against prohibition $\rightarrow$

Stage 6: National executives and/or party leaders intervene to stop the prohibitionist proposal.

The prohibitionist streak in the Anglo-American societies, on the other hand, is not politicized by far right parties or groups and does not primarily aim to ban the religiously 
motivated practice of small Jewish and Muslim minorities, and has been far less successful in opening up a debate at the national level and provoking a legislative or an executive intervention. In the United States and the United Kingdom, where a large percentage of the Christian-heritage males are customarily circumcised as infants, there is indeed a movement of circumcised adult males of Christian-heritage, albeit a small minority, who are mobilized against this practice. Thus, in stark contrast to the Western European context, it is possible to consider the prohibitionist movement in the Anglo-American context, at least in part, as a grassroots movement by those who self-identify as "victims" of this practice. Perhaps seemingly paradoxically, however, the prohibitionist cause has been much less successful, from a legal, medical, and legislative point of view in precisely these Anglo-American contexts where it has been most widespread. Although I refer to the cases of the United Kingdom and the United States in my general discussion of circumcision worldwide, they will not be the focus of this paper. Muslim-majority polities and the only Jewish-majority polity, Israel, where circumcision is relatively uncontested, also fall beyond the scope of my article as they have very different constellations of political, legal, and medical actors, and have pro-circumcision public opinion compared to the Western European cases discussed in this article. Before turning to an examination of comparative political dynamics, it is worth reviewing the medical and legal debates on male circumcision, however very briefly, at least to observe the inconclusive and contested nature of the medical and legal opinions on this subject.

\section{Medical Scholarship on Circumcision}

In two highly noted randomized trials in Kenya and Uganda, teams of scholars found that male "circumcision significantly reduces the risk of HIV acquisition in young men in Africa" (Bailey 
et al. 2007), and moreover, "without behavioral disinhibition," and thus, circumcision "can be recommended for HIV prevention in men" (Gray et al. 2007). Furthermore, comprehensive randomized experiments also indicate that "male circumcision does not adversely affect sexual satisfaction or clinically significant function in men" (Kigozi et al. 2008, 66). As a result of these and other similar medical findings, American Academy of Pediatrics Task Force on Circumcision (2012), in their "Circumcision Policy Statement," argue that the "[e]valuation of current evidence indicates that the health benefits of newborn male circumcision outweigh the risks and that the procedure's benefits justify access to this procedure for families who choose it." According to this policy statement, the "[s]pecific benefits [of circumcision] identified included prevention of urinary tract infections, penile cancer, and transmission of some sexually transmitted infections, including HIV" (American Academy of Pediatrics Task Force on Circumcision, 2012). Although much less supportive than its American counterpart, the British Medical Association's official guidelines for doctors on the topic of circumcision largely condone this practice when requested by both parents (British Medical Association, 2004). In fact, the efficacy of male circumcision as a tool for HIV prevention gained such widespread acceptance that a considerable portion of the medical scholarship focused on different strategies to overcome the resistance to and increase the prevalence of circumcision in different Christianheritage Sub-Saharan African countries such as Malawi (Parkhurst, Chilongozi, and Hutchinson 2015) and Tanzania (Downs et al. 2017).

There are also numerous critics of the medical arguments in favor of circumcision, however, both from within and from outside the field of medicine. Fox and Thomson sharply criticize the British Medical Association's guidelines for condoning non-therapeutic (including religiously motivated) circumcision of infant males for being "uncharacteristically tolerant of 
risks inflicted on young children, given the absence of clear medical benefits" $(2005,463)$. There are also some who question whether there is "really enough of the right kind of evidence" demonstrating the efficacy of circumcision as a "prevention technology" against HIV (Dowsett and Couch 2007). From a rather different angle, Robert Darby (2003) argues in a critical historiographic essay that "the masturbation taboo" was the major and explicitly articulated motivation for the rise of routine male circumcision in Anglophone societies, which in his view explains, at least in part, the rather high prevalence of male circumcision in these otherwise Christian-heritage societies. That being said, male circumcision is also common in some other Christian-heritage countries such as the Philippines (Lee 2006), in addition to Christian-heritage Sub-Saharan African countries mentioned earlier.

\section{Legal Scholarship on Circumcision}

The legal scholarship is similarly divided over the question of infant male circumcision. Merkel and Putzke, reference to the German debates following the Cologne District Court's decision, argue in favor of prohibition of circumcision based on "the boys' right to bodily integrity as well as self-determination" $(2013,444)$. Askola, reference to the Supreme Court of Finland's decision, draws attention to the ambiguity of "informed consent" by parents (single parent or both?); the age of consent for children at which point they can also object to circumcision; the permissibility of using public funds for the procedure; and whether medical professionals can refuse to perform a circumcision "on grounds of conscience... considering the Finnish medical establishment is strongly against circumcision" (Askola 2001, 109). In contrast, there are also arguments against banning circumcision, pointing out the dangers of using “children's rights' discourse in the political arena" given "definitional problems, selectivity and the indeterminacy 
of the best interests standard" as they relate to children's interests (Schuz 2015, 347), and emphasizing that gender and children's rights-based arguments "must not obscure the fact that minority rights sometimes rightfully allow a minority to do things the majority does not understand" (Swatek-Evenstein 2013, 42).

Proponents of prohibition often question the courts' assumptions regarding health benefits, negligible pain and the possibility of future complications that underpin, at least in part, the case for permitting circumcision when parents demand/approve of it. For example, Askola argued that "some of the assumptions made by the [Supreme Court of Finland] are questionable and the outcome of the case leaves public policy in a state of uncertainty, requiring legislative action by the government" $(2011,100)$. In contrast, opponents of circumcision ban question the Western-centric and/or secular(ist) definitions of children's "best interests," and ask whether the state or the parents may have a better understanding of the children's best interests, while emphasizing the tortuous history of religious minority rights in Europe and the necessity of limiting state intervention in the sphere of family life, among other issues. Although it is impossible to do justice to the voluminous legal scholarship on circumcision debates, suffice it to say that the debate is framed around balancing various rights and interests, such as "the right of parents to raise their children, their right to free exercise of their religion, and the right of a child to bodily integrity," while also recognizing "that circumcision served as a rite of passage to document cultural and religious membership in the Muslim community" (Abraham 2017, 1748).

\section{Bringing together Law, Medicine, and Politics in Circumcision Debates}

The various legal and medical debates and opinions briefly reviewed above provide the necessary background in understanding the first stage in the causal process that triggered the 
attempts to ban the circumcision of male children in all the Western European polities examined in this article, namely, the legal (in the case of the District Court of Cologne in Germany) or medical (in the case of all the Scandinavian medical associations) initiative or opinion in favor of banning circumcision. This first stage in the attempt to ban circumcision, whether undertaken by legal or medical actors, was invariably followed by a causal chain dominated by political actors and civil society organizations both at the national and the international level. This paper attempts to outline the causal narrative of failed attempts at banning circumcision in seven Western European polities in the second decade of the $21^{\text {st }}$ century (Figure 1). In outlining such a causal narrative, I emphasize the striking similarity of the successive stages, including the specificity of the actors that became prominent in each stage, either leading the charge in favor or against banning circumcision, across these seven countries. I also briefly discuss legal and medical challenges launched against circumcision that nonetheless fall short of a nationwide prohibition in an eighth case, Finland. "Causal mechanisms, cross-case analyses, and case studies form the research triad" (Goertz 2017, 1) and I seek to follow a multimethod research approach to address my empirical puzzle. First, I review the case of Germany, and the cases of Austria and Switzerland since their short-lived prohibitionist episodes were primarily "spillovers" of an administrative and political kind due to the decision of the District Court of Cologne in Germany. While the German case is the best-known case and the one where the prohibition was briefly implemented, it also has a somewhat different causal chain than the four Scandinavian cases that follow in that legal, rather than medical, actors triggered the prohibitionist attempt. The case of Finland is also briefly referenced as one where legal activism from below sought prohibition, but repeatedly failed so far. It is in Denmark, Sweden, Norway, and Iceland, that the overlapping consensus of medical professionals, far right parties, and anti-circumcision public 
opinion facilitated the advancement of prohibitionist proposals to the national parliaments, where, after very promising beginnings, they were ultimately defeated primarily if not solely due to international outcry and intervention by Jewish and Muslim actors and organizations.

\section{Germany: Activist Judiciary, Anti-Circumcision Public Opinion, and International Stigma}

A few days after his circumcision in 2010, a four-year old Muslim boy was brought to the hospital due to bleeding related to the circumcision. Based on this case, on May 7, 2012, the District Court of Cologne decided that circumcision amounts to "causing bodily harm to another person by using a dangerous instrument.” (Landgericht Köln 2012; Landgericht Cologne 2012). In other words, it was judicial activism on the part of the District Court of Cologne that criminalized a Judeo-Islamic religious practice that was hitherto allowed under German law, at least since the end of the National Socialist regime.

The court decision in Cologne, rather than any political party or societal activism against circumcision, politicized this issue in Germany, and eventually, internationally. As the issue was politicized, the mainstream German media, including Frankfurter Allgemeine Zeiting (FAZ), Die Welt, and Der Spiegel, appeared to be supportive of banning circumcision (Yurdakul 2016, 81). As mentioned earlier, charges were also brought against an Israeli rabbi living and performing circumcisions in Germany after this verdict (Nadeau 2012). The debates around the circumcision controversy in Germany following the Cologne court decision almost immediately spread to the international media, such that in "the Israeli daily newspaper, Haaretz, the circumcision debate was a daily discussion," and according to the European Rabbis Conference, this ruling was "the most serious attack on Judaism since the Holocaust" (Yurdakul 2016, 83). The reactions from Turkey, the country of origin for most of Germany's Muslim citizens, were much more limited. 
Likewise, although there have been many Muslim-origin members of the German parliament (8 in 2009-2013), they have not been outspoken against attempts to restrict Islamic religious practices in general (Aktürk 2018, 44-46), which reflects what I originally depicted as the "representation gap" between "conservative Turks and their leftist representatives" in German politics (Aktürk 2010, 71-72). The international publicity to shame Germany for banning circumcision, spearheaded by the Jewish associations, worked nonetheless, as Chancellor Angela Merkel opined that she does not want to see Germany turning into the laughing stock (komiker nation) of the world over the circumcision ban (Spiegel 2012).

On December 12, 2012, the lower chamber of the German parliament, the Bundestag, effectively overruled the Cologne court decision with the passage of a new law allowing for the circumcision of infant males on the basis of religious justifications upon the request of their parents, "if conducted in accordance with medical practice or if carried out within six months of the birth of the child by persons appointed for such purpose by religious communities" (Schuz 2015, 360). Nonetheless, 100 members of the parliament voted against the new law, while 46 members abstained and 434 voted in favor, providing the supermajority necessary for the passage of the law as expected (Bundestag 2012). It is more significant for the causal narrative of this article (Figure 1) that "a public opinion survey shows that $70 \%$ of the population do not support the new law" that allows for religious circumcision in Germany (Schuz 2015, 360), which is rather similar to the public opinion in the Scandinavian countries such as Denmark and Iceland. Once banning male circumcision became a real possibility and the issue was sufficiently politicized to be the subject of a public opinion survey, both German and Scandinavian publics appeared to be more supportive of banning circumcision rather than allowing it. Finally, it is also noteworthy that the new law was nonetheless a more restrictive development than the status quo 
ante, since in the Islamic tradition, children are circumcised much later than first six months after birth, typically until they are seven years old. In other words, given that the overwhelming majority of the male children that undergo routine circumcision are Muslims in Germany, it can even be argued that the prohibitionist legal initiative in Germany achieved a limited success by significantly limiting the window of time when children could be circumcised.

\section{Austria and Switzerland: Spillover through Administrative Fiat and Local Government}

Following the decision of the District Court of Cologne in Germany, at least one Swiss hospital, the Children's Hospital in Zurich, prohibited circumcisions, and the governor of the Western Austrian province of Vorarlberg "ordered state-run hospitals to stop circumcisions except for health reasons until the legal situation is clarified" in July 2012 (Telegraph 2012). In addition to the state of Vorarlberg, a children's hospital in Graz, the capital of the state of Styria in southeastern Austria, also decided not to perform any more circumcisions (Times of Israel 2012). "Meanwhile, another children's hospital, located in the city of St. Gallen in northeastern Switzerland, has also decided to reassess its policy on circumcision" (Haaretz 2012). According to Pinchas Goldschmidt, the president of the Conference of European Rabbis, the prohibitions in Austria and Switzerland confirmed their "fears that the court ruling in Cologne could have a knockon effect across Europe" (Guardian 2012). Apart from the apparent and gradual spillover of the ban from Germany to Austria and Switzerland, and from one region or hospital to another within these countries, two other characteristics of the Austrian and Swiss cases are noteworthy for my causal narrative (Figure 1) in this paper. First, that the medical professionals, represented by particular local hospitals, appeared to have been sufficiently opinionated against circumcision such that they took an initiative in what may be called "medical activism" in discontinuing 
circumcisions even though no such legal or political step in that direction has been taken in Austria or Switzerland. Second, as evidenced by the prohibitionist initiative of Vorarlberg's governor, Markus Wallner, from the center-right conservative Austrian People's Party (ÖVP), local politicians also proactively contributed to spreading the circumcision ban. Finally, two other developments that are typical of the causal narrative I observe and outline in this article took place in Austria, breaking the prohibitionist wave. First, international media begin to shame Austria with headlines such as "Circumcision Ban in Hitler's Homeland" (American Interest, 2012). Second, an executive intervention at the national level ended the suspension of circumcisions in Vorarlberg, Styria, and anywhere else in Austria, when Justice Minister Beatrix Karl released a letter informing doctors "that they can perform the religious practice without risking criminal charges" (Reuters 2012). In sum, the short-lived and local (e.g., Zurich, Vorarlberg, Graz) circumcision bans in Austria and Switzerland were possible primarily due to medical and local political activism that nonetheless needed the prohibition in Germany as a reference point and justification to enact such a prohibition in their own countries or localities.

\section{Finland: Court Cases against Muslim (2004-2008) and Jewish parents (2010)}

In conformity with the general pattern observed in Northern European countries, the "Finnish Union of Medical Doctors (Suomen Laakariliitto) is against non-medical circumcision on the grounds that the procedure involves risk, inflicts pain and injury, and violates the child's right to decide about his body" (Askola 2011, 104). There were at least two attempts to penalize circumcision of male infants for religious purposes in Finland, which received substantial media and scholarly coverage. The first case, against a Muslim mother, went all the way up to the 
Supreme Court and failed, while the second case, against Jewish parents, succeeded and culminated in a monetary fine.

In the first case, a four and a half years old Muslim boy was circumcised in September 2004. His mother, who was his sole guardian, was charged with assault in the District Court of Tampere in 2006, and although the District Court considered the circumcision procedure as an assault under the Criminal Code, it found the mother's behavior excusable and not deserving of punishment, in part because "the state of the law [with regards to circumcision] was unclear and rather inconsistent" (Askola 2011, 104-105). The case then proceeded to the Court of Appeals in Turku, which concluded that the mother "had not committed an assault as the operation had been performed by a doctor, with professionalism and without causing pain or permanent damage" (Askola 2011, 106). Finally, the case went to the Supreme Court of Finland in Helsinki, which ruled in late 2008, arguing "that male circumcision on social and religious grounds, when 'appropriately performed', is not illegal and therefore not punishable as an assault" (Askola 2011, 106). Thus, the legal permissibility of circumcision for religious purposes was confirmed at the highest level, despite the prohibitionist views of the Finnish medical doctors.

In contrast, a Finnish Jewish couple who brought in a British rabbi to circumcise their son was fined 1,500 Euros in damages that they were obliged to pay their child due to the fact that the rabbi was not a medical doctor and the son was hospitalized after the circumcision due to bleeding (Elgot 2010). It is also noteworthy that when the boy was hospitalized after the circumcision with heavy bleeding, he was treated at the Helsinki University Hospital by Dr Harry Lindahl, who "is a well-known campaigner in the Finnish press against circumcision" and Dr Lindahl "was later called as an expert witness in the case" (Elgot 2010). In short, the espoused views of medical 
doctors against circumcision, both in Finland in general and that of a specific doctor in this case, seem to have a notable effect, albeit not sufficiently decisive to legalize prohibition.

\section{Agents of Scandinavian Prohibitionism:}

\section{Ombudsmen, Medical Professionals, Public Opinion, Far Right, and the "Intactivists"}

In Denmark, Sweden, Norway, and Iceland, medical professionals, far right parties, and anti-circumcision public opinion facilitated the discussion of circumcision bans in the national parliaments, where, despite popular and professional support and promising beginnings, they were ultimately defeated. Indeed, the "children's ombudsmen of all Nordic countries-Finland, Iceland, Denmark, Sweden and Norway—released a joint declaration in 2013 proposing a ban [on circumcision]" (European Jewish Congress 2018).

Sweden, 2013-2018: Ombudsman, Medical Professionals, and the Far-Right Sweden Democrats Sweden provides a good example of the overlapping consensus between medical professionals and far right political parties that propelled the prohibitionist initiatives across Scandinavia. On September 24, 2013, the Ombudsman for Children in Sweden, "Frederik Malmberg, together with representatives from the Swedish Society of Medicine (SLS), the Swedish Society of Health Professionals (Vardförbundet), the Swedish Paediatric Society (BLF) and the Swedish Association for Pediatric Surgeons (SLF)" wrote in an article published in the Swedish daily newspaper Dagens Nyheter that "to circumcise a child without medical reasons and without the child's consent, runs contrary... to the child's human rights and the fundamental principles of medical ethics" (ARC 2013). Very soon thereafter, on September 28, 2013, two legislators from the far-right Sweden Democrats party, Bjorn Soder and Per Ramhorn, submitted 
a motion to the Riksdag, the Swedish parliament, "to ban the non-medical circumcision of males younger than 18" (Haaretz 2013). In January 2014, "the Sweden Medical Association, which counts $85 \%$ of the country's physicians as members, recommended setting twelve as the minimum age for the [circumcision] procedure and requiring a boy's consent in a resolution which was unanimously passed by the ethics council" (Huffington Post 2014). Sweden Democrats experienced a meteoric rise in the polls in the following years, becoming the third-largest party in the parliament with 18 percent of the seats, and they proposed once again "a ban on non-medical circumcision of boys" under the age of 18 , which they described as "backward child abuse" (European Jewish Congress 2018).

Norway, 2017: Ombudsman, Medical Professionals, and the Far-Right Progress Party In May 2017, the Progress Party, the junior partner of the coalition government and the third largest party of Norway, voted to ban circumcision of boys under the age of 16 (Revesz 2017). It was interpreted as a somewhat symbolic vote since the party knew it could not muster a majority for its passage in the parliament, and it was also noted that the vote came "a day after Belgium's Parliament in Wallonia voted in favour of banning ritual slaughter, which would affect Jewish kosher and Muslim halal rituals" (Revesz 2017). In an initiative of more immediate and substantive consequence, it was revealed by a Norwegian newspaper in July 2018 that at least two hospitals in the country, Stavanger University Hospital and Haukeland University Hospital in Bergen, began "refusing to service parents who wish to have their underage male children circumcised" (Jewish Telegraphic Agency 2018). 
Denmark, 2016-2018: Ombudsman, Medical Professionals, Public Opinion, and the Intactivists

In December 2016, the Danish Medical Association released a statement recommending that "no boys under the age of 18 be circumcised in Denmark" (Local 2016). At the time, "polls have shown that upwards of 87 percent of Danes have expressed support for banning the practice [of circumcision] on boys under the age of 18" (Local 2016). Danish authorities estimated that "somewhere between 1,000 and 2,000 circumcisions are performed in Denmark each year" and "beginning in 2017 all circumcisions, regardless of where they take place, will need to be reported to Denmark's national patient registry (Landspatientregistret)" (Local 2016).

Unique among the countries examined in this article, there was a signature campaign organized by the anti-circumcision lobby group, Intact Denmark, which, by collecting more than 50,000 signatures by June 2018 in support of a circumcision ban under the age of 18 , forced the Danish parliament to discuss the issue. Some Danish MPs were put off by Intact Denmark's claim that "Denmark has neglected to comply with international regulations by allowing male circumcision," and they did not want to vote for a new circumcision regulation that would implicitly support the claim that Denmark failed to comply by international regulations on this issue before (Local 2018). Moreover, Intact Denmark's demand, voiced in the petition, to impose a "gender-neutral age of 18 years for circumcision" paradoxically drew the criticism of the far right Danish People's Party, an MP of which "criticized the proposal as it is currently worded, arguing that it would legalize female circumcision" (Local 2018). The Liberal (Venstre) party, throughout its health spokesperson, likewise argued that Denmark currently abides by the UN Convention on Children's Rights and that "it is completely unacceptable and irresponsible to allow circumcision of women" (Local 2018). In sum, none of the largest three parties supported the proposal, mainly due to the wording of the petition, which suggested that Denmark was in violation 
of its international obligations regarding circumcision and could have opened up the possibility of female circumcision (Local 2018).

Iceland, 2018: Ombudsman, Medical Professionals, Popular Opinion, and Political Parties

Of all the European countries, Iceland arguably came closest to prohibiting male circumcision in 2018. The actors and the causal sequence of the initiation and the failure of the Icelandic attempt at prohibition are very similar to those observed and discussed in other Scandinavian countries, and thus, support the main causal narrative of this article in six stages (Figure 1). The most significant difference (of degree, not kind) in the Icelandic attempt is the multiparty agreement in support of prohibiting circumcision, which evaporated in just three months, leading to the dismissal of the proposal by a parliamentary committee, without ever having the opportunity to be voted on. No other European country (at least none examined in this article) had such a broad political partisan agreement in favor of prohibiting circumcision, including all the major political parties, in initiating the discussion to ban circumcision.

It was reported in late January 2018 and became official in February 2018 that members of the Icelandic parliament from at least four political parties, including the Progressive Party and the Left-Greens, which together formed the coalition government, supported a bill to ban circumcision of boys under the age of 18. Silja Dögg Gunnarsottir, a member of the parliament from the Progressive Party, was the spokesperson of the bill (Grapevine 2018a). The bill proposed "a penalty of up to six years in prison for anyone carrying out a circumcision other than for medical reasons" (Sherwood 2018). Out of a total population of 336,000, Iceland was estimated to have "some 250 Jews and about 1,500 Muslims," the two groups whose infant males often went through religiously justified circumcision (Sherwood 2018). 
As in the other Nordic countries and Germany, both the medical professionals and the public were mostly if not overwhelmingly in favor of prohibiting circumcision. In a tiny country of 336,000 people, 400 Icelandic doctors supported the bill, as well as 1,325 nurses and midwives, who signed a petition sent to the Parliament in support of prohibiting circumcision (Grapevine 2018b). In a public opinion poll by a marketing firm, $50 \%$ of the people supported the bill, while $37 \%$ opposed it, and 13\% did not have an opinion either way (Grapevine 2018c). Moreover, as in Denmark, a grassroots organization with transnational links opposing non-medical circumcision, Intact Iceland, was founded and supported the bill (Grapevine 2018d). In short, given broad crossparty endorsement among members of the parliament who jointly proposed it, overwhelming support among the medical professionals, and significant public support overall, the bill to outlaw circumcision in Iceland seemed poised to be approved.

International protests, pressure, and shaming once again became the decisive factor that led to the dismissal of the bill by a parliamentary committee before being voted on. "Should Iceland ban male circumcision, making it impossible for Jews and Muslims to raise families in your country, we guarantee that Iceland will be celebrated by neo-Nazis, white supremacists, and other extremists," Jonathan Greenblatt, the CEO of American Anti-Defamation League wrote in a letter to the Icelandic parliament (Grapevine 2018d). Moreover, "Icelandic consulates around the world have received considerable feedback regarding the ban, especially in Germany, the United States and Britain" and "[n]one of this feedback has been positive" (Grapevine 2018e). As a result, the Judicial Affairs and Education Committee of the Icelandic parliament decided to dismiss the proposal in late April 2018, finally ending a three-month drama of national debates and international lobbying (Grapevine 2018f). 


\section{Concluding Remarks and Avenues for Future Research}

The brief overview of failed attempts at banning circumcision of infant males in eight West European countries in the early $21^{\text {st }}$ century demonstrates a very similar causal pattern with a similar constellation of domestic and international actors positioned in favor and against the prohibition. Both medical professionals and the public opinion at large in almost all of these countries were in favor of banning male circumcision. In addition, in Denmark, Norway, and Sweden, one major far-right political party in parliament spearheaded the proposals for banning circumcision, whereas in Iceland there was initially a multi-party agreement on the ban, including the largest parties that formed the coalition government. Also similarly, in the cases of Germany and Iceland, where a ban on circumcision briefly came into effect through judicial activism and a ban seemed most likely to get parliamentary approval, respectively, very significant international pressure and practices of shaming played a major, arguably the decisive, role in ultimately preventing the prohibition of circumcision.

For many religious individuals, be they Christians, Jews, or Muslims, being able to raise their children in accordance with the minimum requirements of God's law is of paramount importance. Circumcision of infant males is the critical ritual signifying God's covenant with Abraham, and thus, a sine qua non of Jewish identity, even for most secular Jews (Schuz 2015). Circumcision of males is likewise a prophetic tradition (sunnah) that is highly recommended in the Islamic tradition, and although it is not an absolutely compulsory requirement of being a Muslim from a theological point of view, it became a de facto requirement and a rite of passage for Muslim male children as well. As such, prohibiting the circumcision of male children would in effect deprive most religious Jews and Muslims from having (male) children in the only way that is acceptable from their point of view, and thus, jeopardizing the possibility of a religious 
Jewish and Muslim family life in Europe. Walter Russell Mead (2012) was voicing the view of many opponents of the Cologne court's decision to prohibit circumcision when he wrote that, "the court was essentially criminalizing the practice of Judaism in Germany." Moreover, combined with other legal prohibitions directly threatening necessary components of Jewish and Muslim life, such as the prohibitions on ritual animal slaughter making the production of halal/kosher meat impossible in much of northern Europe (Guttman 2018; Library of Congress 2018), it is very much debatable whether alternative conceptions of the good life that are based on non-Christian religious traditions will be tolerated much longer in these societies.

Many other questions remain regarding failed attempts to ban circumcision in Western Europe. For example, to what extent was the public opinion affected by the medical professionals' opinion regarding circumcision, or by the politicization of the issue by far right parties? What explains the overwhelming propensity of medical professionals in Nordic European countries to advocate prohibition of circumcision? Is there any causal significance of the fact that all of these are Protestant and more specifically "Lutheran" polities (Kahl 2005) historically? What explains the timing of these attempts? Is there any peculiarity of the 2010s that facilitated these attempts? Relatedly, what is the role of the proverbial "elephant in the room," namely, Islamophobia, in motivating attempts and shaping the justifications to ban circumcision? Is there any connection between the wave of mostly successful prohibitions against another Judeo-Islamic religious practice, namely, ritual animal slaughter, in eight Western European countries (Library of Congress 2018), and the attempts at circumcision bans? Finally, what are the theoretical and practical significance of the normative arguments in favor of or against prohibiting circumcision? How do these arguments relate to the ongoing debates on (the crisis of) liberalism; the nexus between the state, the family, and the individual; and the toleration of different conceptions of the 
good life, both at the international and the subnational levels? These questions underline the practical and theoretical significance of the debates over prohibiting circumcision, and provide fruitful avenues for further research.

\section{REFERENCES}

Abraham, David. 2017. "Circumcision: Immigration, religion, history, and constitutional identity in Germany and the US." German Law Journal 18, no. 7: 1745-1762.

Aktürk, Sener. 2010. "The Turkish minority in German politics: trends, diversification of representation, and policy implications." Insight Turkey 12, no. 1: 65-80.

Aktürk, Sener. 2018. Political Engineering and the Exclusion of Religious Conservative Muslims in Europe. Istanbul: SETA.

American Academy of Pediatrics Task Force on Circumcision. 2012. "Circumcision Policy Statement.” Pediatrics 130, no. 3: 585. doi:10.1542/peds.2012-1989

American Interest. 2012. "No Snips in Austria? Circumcision Ban in Hitler's Homeland." The American Interest, July 29, 2012. Available at $<$ https://www.the-americaninterest.com/2012/07/29/austrian-province-against-circumcision/>.

Amir-Moazami, Schirin. 2016. "Investigating the secular body: the politics of the male circumcision debate in Germany." ReOrient 1, no. 2: 147-170.

Androus, Zachary T. 2013. "Critiquing circumcision: in search of a new paradigm for conceptualizing genital modification." Global Discourse 3, no. 2: 266-280.

ARC. 2013. "Good news from Sweden: Officials denounce male circumcision, and bill introduced to ban circumcision." Attorneys for the Rights of the Child. Available at $<$ https://www.arclaw.org/news/good-news-from-sweden-officials-denounce-male-circumcisionand-bill-introduced-to-ban-circumcision> .

Askola, Heli. 2011. "Cut-Off Point? Regulating Male Circumcision in Finland." International Journal of Law, Policy and the Family 25, no. 1: 100-119.f

Bailey, Robert C., Stephen Moses, Corette B. Parker, Kawango Agot, Ian Maclean, John N. Krieger, Carolyn FM Williams, Richard T. Campbell, and Jeckoniah O. Ndinya-Achola. 2007. "Male circumcision for HIV prevention in young men in Kisumu, Kenya: a randomised controlled trial." The Lancet 369, no. 9562: 643-656. 
Banai, Ayelet. 2013. "Circumcision: what should parents and states do? An essay." Global Discourse 3, no. 2: 332-341.

British Medical Association. 2004. "The law and ethics of male circumcision: guidance for doctors." Journal of Medical Ethics 30: 259-263.

Bundestag. 2012."Beschneidung von Jungen jetzt gesetzlich geregelt.” Available at $<$ https://www.bundestag.de/dokumente/textarchiv/2012/42042381_kw50_de beschneidung$\underline{210238}>$.

Darby, Robert. 2003. "The masturbation taboo and the rise of routine male circumcision: a review of the historiography." Journal of Social History 36, no. 3: 737-757.

Downs, Jennifer A., Agrey H. Mwakisole, Alphonce B. Chandika, Shibide Lugoba, Rehema Kassim, Evarist Laizer, Kinanga A. Magambo et al. 2017. "Educating religious leaders to promote uptake of male circumcision in Tanzania: a cluster randomised trial." The Lancet 389, no. 10074: 1124-1132.

Dowsett, Gary W., and Murray Couch. 2007. "Male circumcision and HIV prevention: Is there really enough of the right kind of evidence?." Reproductive Health Matters 15, no. 29: 33-44.

Elgot, Jessica. 2010. "Couple fined for son's circumcision by British rabbi." The JC, February 25, 2010. Available at < https://www.thejc.com/news/world/couple-fined-for-son-scircumcision-by-british-rabbi-1.14164>.

European Jewish Congress. 2018. "Swedish far-right party submits motion calling for circumcision ban." European Jewish Congress, October 8, 2018. Available at $<\underline{\text { https://eurojewcong.org/news/communities-news/sweden/swedish-far-right-party-submits- }}$ motion-calling-for-circumcision-ban/>.

Fox, Mary, and Michael Thomson. 2005. "A covenant with the status quo? Male circumcision and the new BMA guidance to doctors." Journal of Medical Ethics 31, no. 8: 463-469.

Goldman, David P. 2012. "The sacred rite of circumcision." Tablet, August 9, 2012. Available at

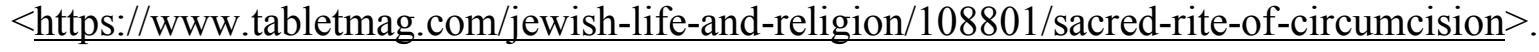

Grapevine. 2018a. "Iceland Wants to Ban Circumcision Of Young Boys."

The Reykjavik Grapevine, January 31, 2018. Available at

$<\underline{\text { https:/grapevine.is/news/2018/01/31/iceland-wants-to-ban-circumcision-of-young-boys/>. }}$.

Grapevine. 2018b. "Catholic Bishop Of Iceland Speaks Up About Circumcision.” The Reykjavik Grapevine, March 8, 2018. Available at $<$ https://grapevine.is/news/2018/03/08/catholic-bishopof-iceland-speaks-up-about-circumcision/>. 
Grapevine. 2018c. "Not So Cut-And-Dry: The Circumcision Controversy Continues." The Reykjavik Grapevine, March 16, 2018. Available at < so-cut-and-dry-the-circumcision-controversy-continues/ $>$.

Grapevine. 2018d. "American Anti-Defamation League Threatens Iceland Because Of Circumcision Ban." The Reykjavik Grapevine, March 22, 2018. Available at $<$ https:/grapevine.is/news/2018/03/22/american-anti-defamation-league-speaks-up-aboutcircumcision-ban/>.

Grapevine. 2018e. "Proposed Child Circumcision Ban In Iceland Prompts Diplomatic Row." The Reykjavik Grapevine, April 4, 2018. Available at

$<$ https://grapevine.is/news/2018/04/04/proposed-child-circumcision-ban-in-iceland-promptsdiplomatic-row/>.

Grapevine. 2018f. "Ban On Circumcision In Iceland To Be Dismissed In Parliament." The Reykjavik Grapevine, April 26, 2018. Available at $<\underline{\text { https://grapevine.is/news/2018/04/26/ban- }}$ on-circumcision-to-be-dismissed-in-parliament/>.

Gray, Ronald H., Godfrey Kigozi, David Serwadda, Frederick Makumbi, Stephen Watya, Fred Nalugoda, Noah Kiwanuka et al. 2007. "Male circumcision for HIV prevention in men in Rakai, Uganda: a randomised trial." The Lancet 369, no. 9562: 657-666.

Guardian. 2012. "Hospitals in Austria and Switzerland suspend circumcision." Guardian, July 25, 2012. Available at $<$ https://www.theguardian.com/world/2012/jul/25/hospitals-in-austriaand-switzerland-suspend-circumcision>.

Guttman, Nathan. 2018. "Why Does Scandinavia Want To Ban Circumcision And Kosher Slaughter?." Forward, March 18, 2018. Available at $<$ https://forward.com/news/world/395213/why-does-scandinavia-want-to-ban-circumcision-andkosher-slaughter/>.

Haaretz. 2012. "Austria Province to Join Growing Ban on Religious Circumcisions." Haaretz, July 24, 2012. Available at $<$ https://www.haaretz.com/jewish/austrian-hospitals-joincircumcision-ban-1.5270410>.

Haaretz. 2013. "Motion to ban non-medical circumcision introduced in Sweden." Haaretz, September 24, 2013. Available at $<$ https://www.haaretz.com/jewish/sweden-to-bancircumcision-1.5339779>.

Hirschkind, Charles. 2011. "Is there a secular body?." Cultural Anthropology 26, no. 4: 633-647.

Huffington Post. 2014. "Ritual Circumcision Ban Recommended in Sweden and Denmark by Medical Associations." Huffington Post, January 27, 2014. Available at $<$ https://www.huffpost.com/entry/circumcision-ban-sweden-denmark_n_4674547>. 
Jewish Telegraphic Agency. 2018. "Norwegian hospitals refuse to assist in circumcisions." Jewish Telegraphic Agency, July 11, 2018. Available at $<\underline{\text { https://www.jta.org/2018/07/11/global/norwegian-hospitals-refuse-to-assist-in-circumcisions }>\text {. }}$.

Kahl, Sigrun. 2005. "The religious roots of modern poverty policy: Catholic, Lutheran, and Reformed Protestant traditions compared." European Journal of Sociology 46, no. 1: 91-126.

Kigozi, Godfrey, Stephen Watya, Chelsea B. Polis, Denis Buwembo, Valerian Kiggundu, Maria J. Wawer, David Serwadda et al. 2008. "The effect of male circumcision on sexual satisfaction and function, results from a randomized trial of male circumcision for human immunodeficiency virus prevention, Rakai, Uganda." BJU international 101, no. 1: 65-70.

Landgericht Cologne. 2012. "Judgment 151 Ns 169/11." Available in English translation at $<$ https://www.dur.ac.uk/resources/ilm/CircumcisionJudgmentLGCologne7May20121.pdf $>$.

Landgericht Köln. 2012. "Urteil 151 Ns 169/11.” Available in German original at $<$ http://www.justiz.nrw.de/nrwe/lgs/koeln/lg_koeln/j2012/151_Ns_169_11_Urteil_20120507.ht $\underline{\mathrm{ml}}>$.

Lee, Romeo B. 2006. "Filipino experience of ritual male circumcision: Knowledge and insights for anti-circumcision advocacy." Culture, health \& sexuality 8, no. 3: 225-234.

Levey, Geoffrey Brahm. 2013. "Thinking about infant male circumcision after the Cologne court decision." Global Discourse 3, no. 2: 326-331.

Library of Congress. 2018. "Legal Restrictions on Religious Slaughter in Europe." Available at $<$ https://www.loc.gov/law/help/religious-slaughter/religious-slaughter-europe.pdf $>$.

Local, The. 2016. "Danish doctors come out against circumcision." The Local, December 5, 2016. Available at $<$ https://www.thelocal.dk/20161205/danish-doctors-come-out-againstcircumcision>.

Local, The. 2018. "Petition for Danish circumcision ban loses political support." The Local, November 16, 2018. Available at $<$ https://www.thelocal.dk/20181116/petition-for-danishcircumcision-ban-loses-political-support>.

Mead, Walter Russell. 2012. "Jews and Muslims United to Fight Germany for Basic Human Freedom." The American Interest, June 28, 2012. Available at $<$ https://www.the-americaninterest.com/2012/06/28/jews-and-muslims-unite-to-fight-germany-for-basic-humanfreedom/?.ga $=2.40090148 .763108884 .1566764982-1208484455.1564088916>$.

Merkel, Reinhard, and Holm Putzke. 2013. "After Cologne: male circumcision and the law. Parental right, religious liberty or criminal assault?." Journal of Medical Ethics 39, no. 7: 444449. 
Morris, Brian J., Richard G. Wamai, Esther B. Henebeng, Aaron AR Tobian, Jeffrey D.

Klausner, Joya Banerjee, and Catherine A. Hankins. 2016. "Estimation of country-specific and global prevalence of male circumcision." Population Health Metrics 14, no. 1: 1-13.

Nadeau, Barbie Latza. 2012. "Cut it out: Europe goes after circumcision.” Daily Beast, August 24, 2012. Available at https://www.thedailybeast.com/europe-goes-after-circumcision

Parkhurst, Justin O., David Chilongozi, and Eleanor Hutchinson. 2015. "Doubt, defiance, and identity: understanding resistance to male circumcision for HIV prevention in Malawi." Social Science \& Medicine 135: 15-22.

Reuters. 2012. “Austrian Justice Ministry gives OK for circumcisions.” Reuters, July 30, 2012. Available at $<$ https://www.reuters.com/article/oukwd-uk-austria-circumcisionidAFBRE86T0Z920120730>.

Revesz, Rachael. 2017. "Norwegian ruling party votes to ban circumcision for men under 16 years old." Independent, May 8, 2017. Available at $<$ https://www.independent.co.uk/news/world/europe/norwegian-ruling-progress-party-bancircumcision-men-under-16-years-old-vote-annual-conference-a 7723746.html $>$.

Sherwood, Harriet. 2018. "Iceland law to outlaw male circumcision sparks row over religious freedom." Guardian, February 18, 2018. Available at $<$ https://www.theguardian.com/society/2018/feb/18/iceland-ban-male-circumcision-firsteuropean-country>.

Schuz, Rhona. 2015. "The Dangers of Children's Rights' Discourse in the Political Arena: The Issue of Religious Male Circumcision as a Test Case." Cardozo Journal of Law \& Gender 21, no. 2: 347-392.

Shweder, Richard A. 2013. "The goose and the gander: The genital wars." Global Discourse 3, no. 2: 348-366.

Spiegel, Der. 2012. "Kanzlerin warnt vor Beschneidungsverbot.“ Spiegel Online, July 17, 2012. Available at $<\underline{\text { https://www.spiegel.de/politik/deutschland/bundeskanzlerin-merkel-warnt-vor- }}$ beschneidungsverbot-a-844671.html $>$.

Swatek-Evenstein, Mark. 2013. "Limits of Enlightenment and the Law - On the Legality of Ritual Male Circumcision in Europe Today." Merkourios: Utrecht Journal of International and European Law 29, no. 77: 42-50

Telegraph. 2012. "Hospitals in Austria and Switzerland suspend circumcision." Telegraph, July 25, 2012. Available at $<$ https://www.telegraph.co.uk/news/worldnews/europe/austria/9427592/Hospitals-in-Austriaand-Switzerland-suspend-circumcision.html $>$. 
Times of Israel. 2012. "Circumcision ban reaches Austria." Times of Israel, July 25, 2012. Available at $<$ https://www.timesofisrael.com/circumcision-ban-reaches-austria/>.

Van Howe, Robert. 2013. "Infant male circumcision in the public square: applying the public reason of John Rawls." Global Discourse 3, no. 2: 214-229.

Van Howe, Robert S. 2013. "Infant circumcision: the last stand for the dead dogma of parental (sovereignal) rights." Journal of Medical Ethics 39, no. 7: 475-481.

Yurdakul, Gökçe. 2016. "Jews, Muslims and the ritual male circumcision debate: Religious diversity and social inclusion in Germany." Social Inclusion 4, no. 2: 77-86. 